\section{Domestic use of biomass fuel in the rural Meghna floodplain areas of Bangladesh}

\begin{abstract}
Akther $S^{(1)}$, Miah MD ${ }^{(1-2)}$, Koike $M^{(1)}$
Rural households in the developing countries constitute the largest share of the biomass fuel consumption. It is also a major source of energy in the low in come country. However, this energy consumption pattern varies from region to region. Different case studies on the biomass fuel consumption will certainly contribute to the understanding on the energy uses of a nation. The present study was conducted in the rural areas of the Meghna floodplain zone in Bangladesh, with a total of 80 sampled households, using the stratified random sampling technique through the semi-structured questionnaires from November 2008 through February 2009. Firewood, cowdung, leaves and twigs, branches, rice straw and rice husk were used as the biomass fuels mainly for the cooking purpose. Leaves and twigs were found as the dominant biomass fuel as $187 \pm 25.69$ (SE) kg month ${ }^{-1}$ household $^{-1}$. The major source of biomass fuel collection was identified as the own homestead and agricultural lands, $74 \%$. The households spent $14.56 \pm 8.94{\text { US } \$ \text { month }^{-1} \text { household }}^{-1}$ for biomass fuels. The ratio of the total energy expenditure to the total income of the household was around $11 \%$. But, the ratio of the biomass expenditure to the total energy expenditure of the households was $68 \%$. Monthly income, land ownership and family size were found significantly influencing to the biomass energy expenditure. The study will be useful for the policy makers in the renewable energy, forestry and agriculture sector in Bangladesh.
\end{abstract}

Keywords: Demography and energy, Dominant biomass fuel, Energy expenditure, Forests, Sources of biomass fuels

\section{Introduction}

Biomass fuels contribute to the largest share of the energy uses in Bangladesh. Currently, biomass is the fourth larges source of energy which supplies $15 \%$ of the energy use in the world (Sudha \& Ravindranath 1998). Only in the developing countries, traditional biomass fuels meet a large percentage $(38 \%)$ of the total energy needs (Sudha et al. 2003). In some countries like Bangladesh, its use is as so high as $75-90 \%$, mainly used for cooking and heating (Sudha et al. 2003). Woody and non-woody biomass in the form of fuelwood, crop residues and cowdung dominates as the energy source in the low income country. Rural households

(1) Forest Policy Laboratory, Shinshu University, 8304 Minamiminowa-Mura, Kami Ina Gun, 399-4598 Nagano-ken (Japan); (2) Institute of Forestry and Environmental Sciences, University of Chittagong, Chittagong 4331 (Bangladesh)

@, Masao Koike (makoike@shinshu-u.ac.jp)

Received: Mar 03, 2010 - Accepted: Jul 15, 2010

Citation: Akther S, Miah MD, Koike M, 2010. Domestic use of biomass fuel in the rural Meghna floodplain areas of Bangladesh. iForest 3: 144-149 [online: 2010-09-27] URL: http://www.sisef.it/iforest/show.php? id $=551$ are the major consumer in this respect.

About $77 \%$ of the populations in Bangladesh live in the rural areas and they need energy for their domestic use like cooking, crop processing, lighting, agricultural industries, social welfare and commercial activities (BBS 2006). Because of over exploitation of natural and homestead forests, fuel shortage intensity is being increased day by day. In Bangladesh, biomass plays an important role, especially in the rural areas, where most of the people live. The overuse of fuelwood is significantly sharing the deforestation process. In addition to this, there is an increased use of crop residues and cowdung as fuel which is depriving the agricultural soil of valuable nutrients and organic matter. However, the fuel choice by the households is influenced by the income, family size, educational status and the occupation of the household members (Rao \& Reddy 2007)

Sarker \& Islam (1998) studied the household biomass fuel energy situation in the poor forest regions of Bangladesh. Miah et al. (2003) studied the biomass fuel use by the rural households in Chittagong region, Bangladesh. Jashimuddin et al. (2006) investigated the preference and consumption pattern of biomass fuel in some disregarded villages of Bangladesh. Akhter et al. (1999) studied the homestead biomass fuel energy situation of a forest rich district, Cox's Bazar. Rao \& Reddy (2007) studied the variations of energy use by Indian households. Wijayatunga \& Attalage (2002) analyzed the household cooking energy demand and its environmental impact in Sri Lanka. Xiaohua \& Zhenming (1996) carried out a survey of rural household energy consumption in China.

To know the biomass consumption and expenditure pattern in the rural households, no study was so far found in the Meghna floodplain zone of Bangladesh. Thus, the study was conducted to understand the biomass fuel consumption and its expenditure by the rural households in the specified geographical location. The findings of the study are expected to contribute to the sustainable energy development in Bangladesh.

\section{Methodology}

\section{Study area}

The study was conducted at Raipura Upazila (local government unit under a district in Bangladesh) of Narsingdi district (Fig. 1) in Bangladesh. The total area of the Upazila is $312.77 \mathrm{~km}^{2}$, which lies between $23.9607^{\circ}$ North and $90.8750^{\circ}$ East (BBS 2006). The soil formation of the Upazila is flood plain and grey piedmont. The Upazila has a uniform temperature, high humidity and heavy rainfall which occur from June to October. The average annual temperature is maximum $36{ }^{\circ} \mathrm{C}$, minimum $12.7^{\circ} \mathrm{C}$ with annual rainfall 2376 mm (BBS 2006). Raipura Upazila, consists of 24 Union Parishads (local government unit under an Upazila in Bangladesh), 113 Mouzas (smaller units of Union Parishad mainly used for land demarcation) and 241 villages. The total population of the Upazila is 454546 where male 231449 and female 223097 . Among the total population, Muslim populations are $92 \%$, Hindu $7 \%$, and others $1 \%$. The population density is 2219 persons $\mathrm{km}^{-2}$ (BBS 2006). Average literacy of the Upazila is $34 \%$ (BBS 2006). The people of the study area are involved with various occupations. The main occupations include agriculture $41 \%$, commerce $14 \%$, agriculture laborers $13 \%$, weaving $12 \%$, service $5 \%$, wage laborers $3 \%$, fishing $2 \%$, industry $2 \%$, and others $9 \%$ (BBS 2006). Total cultivable land 24393 ha; single crop 31\%, double crop $61 \%$ and treble crop $8 \%$; cultivable land under irrigation 39\% (BBS 2006). The rivers flown over the Upazila are Meghna, Old Brahmaputra, Arial Khan and Kakan. Among them, Meghna is the dominant river flowing inside this Upazila, creating a unique culture and economy in this Upazila. As Raipura Upazila is the plain land, the overflow of Meghna especially at the rainy 


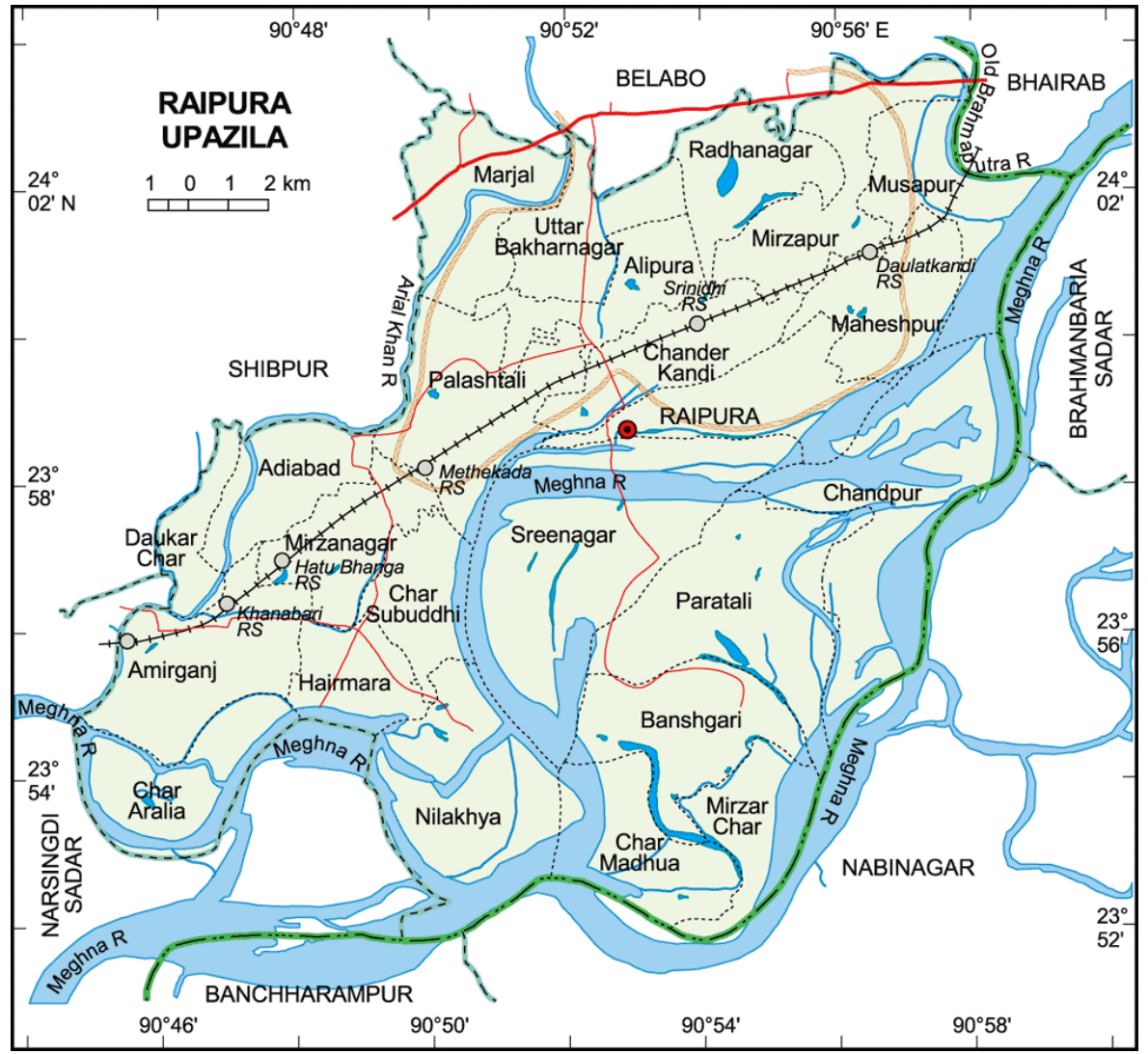

Fig. 1 - Map of Raipura Upazila under Narsingdi district of Bangladesh.

season, creates floods in this area. There is no government-owned forest lands in this Upazila. Only privately-owned homestead forests or village grooves/jungles are present here, but these forests are going to be converted from high-biodiverse to lower ones and from the native species to the exotic species (pers. comm.).

\section{Methods of data collection}

The study was conducted using the stratified random sampling technique over a period of four months, from November 2008 to February 2009. It was a time-intensive case study in which total time frame planned for the study was flexibly considered. On site, locating the samples was completed within 15 days starting from November 2008 and the primary data collection was finished by the end of February 2009. But in research planning, data collection time was selected purposely considering the easiness of data collection, season and availability of research crews. November through February in Bangladesh is usually non-rainy dry period. Data collection at that period was thought to be easier. However, local volunteers' support substantiated to finishing the data collection within four months.

\section{Sampling procedure}

The sequence of sampling was from
Upazila to Union, from union to village and then village to households. Out of 24 Unions of Raipura Upazila, 4 unions were selected randomly as the rural area. The selected unions were Chanderkandi, Mohespur, Paratali and Radhanagar. From each of the selected unions in the rural area, 2 villages were selected randomly. From each of the village, 10 households making 80 in total from the rural area were selected randomly. It was found in the study area that a village had 90120 numbers of households. So, 10 households in a selected village (around 10\% sampling) was considered enough. The list of the unions and its villages were collected from the Upazila administration. After selecting the villages, the households' name and location was identified with the help of the respective Union Parishad office. The randomization was done with the help of the random number table. With the help of the volunteers involved by the ward and Union Parishad office, the final location of the households was determined and thus data collection was easier with the help of them.

\section{Collection of primary data}

Before collecting final data, a reconnaissance survey was carried out to have an overall idea of the study site. However, the final data collection was started from November 2008 and ended on February
2009. The major data included demography of the respondent, land ownership, household dwelling characteristics, types of biomass, biomass source, biomass fuel consumption per month and monthly household expenditure. All kinds of field data were collected by the direct interviewing of the households' head and physical observation. Some of the facts $(5 \%)$ delivered by the respondents were cross-checked with the help of the other neighboring people and key persons in the society. The facts mostly included biomass source, biomass fuel consumption per month and monthly household expenditure. In some cases, a little adjustment in the data was needed with a re-discussion with the respective households.

Household's head was the respondent of the study, where all the respondents were Muslim. Male respondents were highest, $96 \%$, while the female were only $4 \%$ in the study area. The literacy rate of the respondents was $41 \%$. Business was found as the highest, $42 \%$ in all the occupations of the respondents followed by farming, $32 \%$, and so on. Most of the female respondents were housewife, $97 \%$. However, the interviewers were composed of one male and one female at every team. But the local volunteers made our tasks easy to access the facts from the respondents of both male and female.

\section{Data analysis}

To find out the dominant biomass used for energy, frequency of use was confirmed for every end-uses of biomass energy carriers. The frequency of the uses was weighted by the amount used of each biomass type. Then the dominant biomass fuel was ranked with the percentage of each biomass type among the total weights. For analyzing the income and energy expenditure, the national currency measurement was used. The national currency of Bangladesh is taka (tk) which could be converted to US $\$$ as US $\$ 1=$ tk 70 . The conversion can be verified by the average currency exchange rate between taka and US dollars during the study period. The expenditure for each biomass type was calculated summing all the explicit costs of each biomass fuel used by all the households. Biomass fuel used was considered as dry-matter, as the fuels were physically observed and verified to be air-dried at ovendry condition before burning. So, the moisture content of plant derived biomass fuel was assumed to be $20-25 \%$ (Hossain 2003, Sattar et al. 1999). The collected field data were compiled and analyzed with the help of calculator, Microsoft ${ }^{\circledR}$ Excel and statistical package SPSS 13.0. Linear regression analysis was carried out to show the effect of different factors to the energy expenditure. In addition to this, Spearman's rho $(\rho)$ correlation test was carried out to show the relationship between the variables. 


\section{Results and discussion}

Socio-economic background of the households

The average income of the households was $189.70 \pm 59.87$ (SE) US\$ month ${ }^{-1}$, with the maximum 350 US\$ month ${ }^{-1}$ and the minimum 112.65 US\$ month ${ }^{-1}$. About $24 \%$ of the family members in the households were illiterate, while $41 \%$ were primary, $22 \%$ secondary, $6 \%$ higher secondary passed. Only $4 \%$ were graduate and $3 \%$ were post-graduate (Fig. 2). The family size of the households was $5 \pm 1.65$ with the maximum 8 and the minimum 2. Three types of dwelling home were available, where $61 \%$ of the households lived in the Kacha (houses built with traditional construction materials like mud, thatch, etc.) and $23 \%$ in the SemiPucca (houses built with combination of cement, brick and thatch) and $16 \%$ in the Pucca home (houses built with the modern construction materials - Fig. 3).

The study showed that the economic condition and the family size of the households determined the dwelling status. It was clear that, if the family size was higher but the economic condition was not higher, it resulted to constructing Kacha house. It was shown that the income of the households living in the Kacha house was $110 \pm 39.54$ US\$ month $^{-1}$ household $^{-1}$, while it was $210 \pm$ 55.98 US\$ month ${ }^{-1}$ household ${ }^{-1}$ in the Semi-

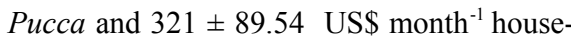
hold $^{-1}$ in the Pucca households (Fig. 3).

\section{Consumption of the biomass fuel}

It was found that the rural households largely depended on the biomass fuel including firewood, branches, leaves and twigs, bamboo, rice straw, rice husk and cowdung. Among the biomass fuels, about $26 \%$ households used firewood, $18 \%$ branches of trees, $31 \%$ leaves and twigs, $5 \%$ bamboo, $4 \%$ rice straw, $7 \%$ rice husk and $9 \%$ cowdung (Fig. 4). But the dominant biomass fuel was leaves and twigs.

Firewood is found always preferable to the households, but most of the rural households are not able to buy firewood with comparatively higher cost than the other biomass (cowdung, leaves and twigs, branches, bamboo, rice straw and rice husk - Arnold et al. 2006, Jashimuddin et al. 2006, Palmer \& Macgregor 2009). Furthermore, women and children can collect those free of cost from their homestead, agricultural land and also from the neighbors (pers. comm.). The rural households who are relatively in good economic condition and educational status, try to use firewood because of their ease of use and burning capacity than that of the other biomass fuels (Van Ruijven et al. 2008). In Mozambique, Brouwer \& Falcáo (2004) found the firewood as the dominant cooking fuel in Maputo city. As income of the city

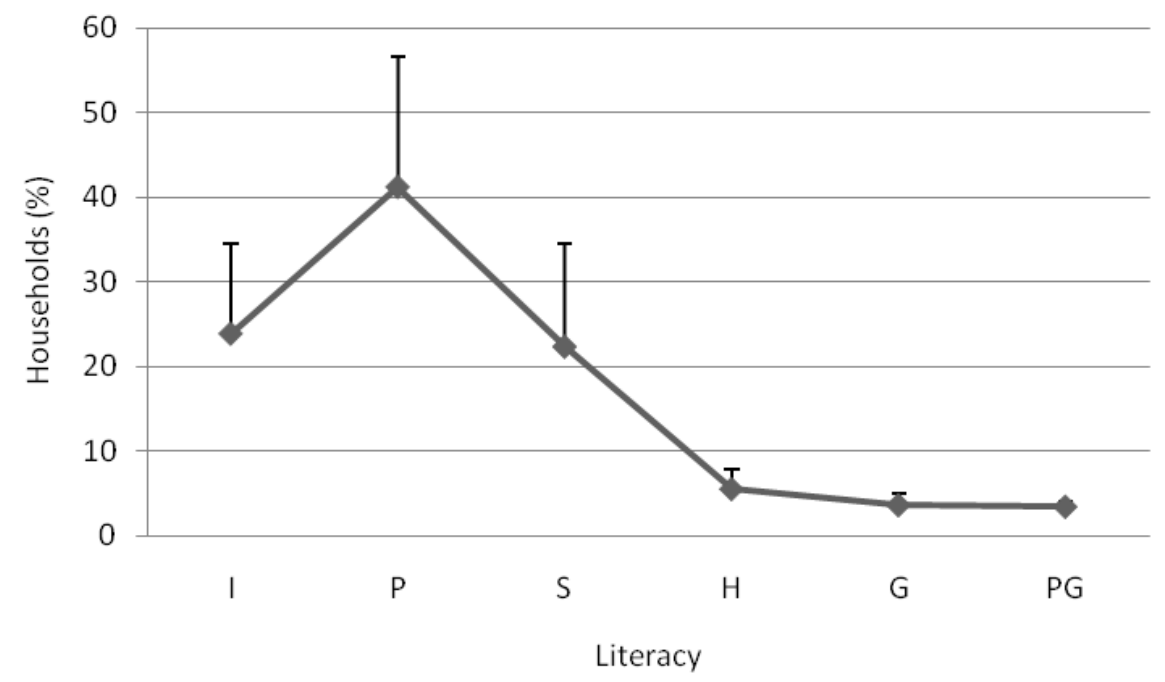

Fig. 2 - Literacy in the rural households in the Meghna floodplain area of Bangladesh. (I): illiterate, $(\mathrm{P})$ : primary, $(\mathrm{S})$ : secondary, $(\mathrm{H})$ : higher secondary, $(\mathrm{G})$ : graduate and $(\mathrm{PG})$ : post graduate. households is more than that of the rural area, they can easily afford buying firewood for their cooking purposes. Households' income as an important driving force for fuel choice has been evident by different studies in the south Asia also (Gupta \& Köhlin 2006, Heltberg 2004, Joon et al. 2009, Rao \& Reddy 2007, Wijayatunga \& Attalage 2002). As income in the rural area is comparatively lower, the households usually like to have the low-cost or free fuels. In this perspective, the dominance of leaves and twigs in the present study can be validated.

It was found that the rural households used leaves and twigs $187 \pm 25.69 \mathrm{~kg}$ month $^{-1}$ household $^{-1}$, branches $162 \pm 35.47 \mathrm{~kg}$ month $^{-1}$ household ${ }^{-1}$, firewood $144 \pm 23.65$ $\mathrm{kg} \mathrm{month}^{-1}$ household $^{-1}$, bamboo $58 \pm 15.26$ $\mathrm{kg} \mathrm{month}^{-1}$ household $^{-1}$, cowdung $42 \pm 19.58$ $\mathrm{kg}$ month $^{-1}$ household $^{-1}$, rice husk $39.47 \pm$
$15.69 \mathrm{~kg} \mathrm{month}^{-1}$ household ${ }^{-1}$ and rice straw $32.64 \pm 15.47 \mathrm{~kg}$ month $^{-1}$ household $^{-1}$, as shown in the Tab. 1.

An average consumption of biomass, 187 $\mathrm{kg}$ month $^{-1}$ household $^{-1}$ was from the leaves and twigs as the highest, because those were available in the rural area and it was easy to collect by women and children. Different studies (e.g., Balat \& Ayar 2005, Mahapatra \& Mitchell 1999, Mahiri 2003, Wijayatunga \& Attalage 2002) indicate that collected fallen leaves of trees reduce the soil organic matter in the homestead forest floor. Their studies also show that due to over collection of biomass fuels, soil productivity reduce significantly. A frequent and over collection of leaves and twigs from the remnant of the rural jungles near to the studied households was observed during the study period. The lack of litter presence in the forest floor also

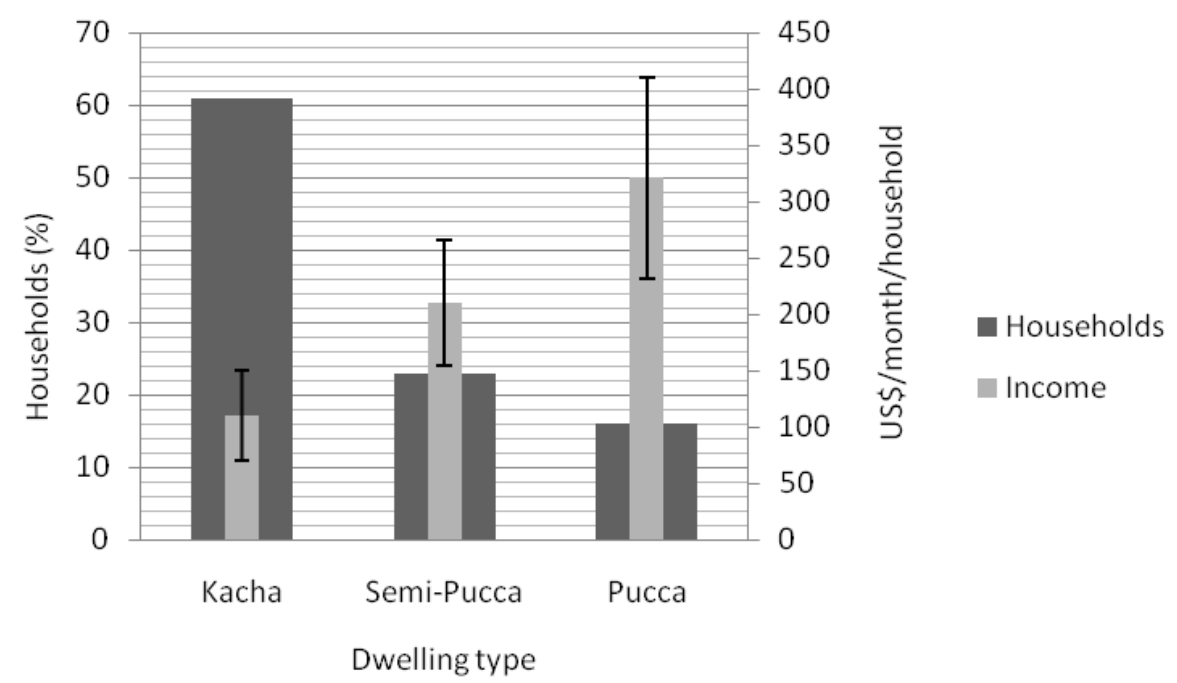

Fig. 3 - Income and dwelling type of the rural households in the Meghna floodplain area of Bangladesh. 
Fig. 4 - Biomass fuel consumption as dominance ranking in the Meghna floodplain area of Bangladesh.

Fig. 5 - Biomass fuel sources in the Meghna floodplain area of Bangladesh.
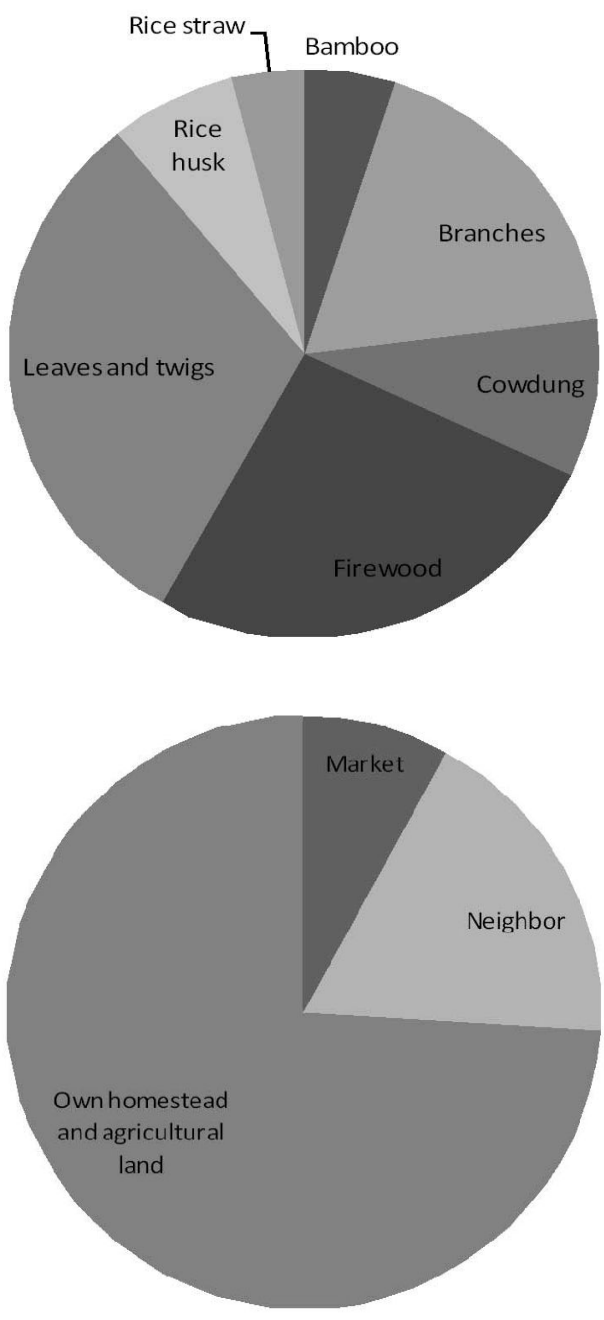

was observed in the limited time period from November 2009 through February 2009. The interactions between weather, vegetation structure and land use, on local to regional scales and across a variety of temporal scales, lead the forest fire ignition, spread, and impacts (Flannigan 2006, Martín et al. 1997). Bangladesh, a country of sub-tropical climate, possesses the tropical moist evergreen, semi-evergreen and deciduous forests (Iftekhar 2006). Homestead forests/jungles also represent the tropical moist type of

forests. The present climatic and vegetation characteristics never support any wild forest fire in Bangladesh. Even though, Wright et al. (2007) report some forest fire cases in some tropical countries. However, the clearing of the forest floor in Bangladesh is not inter-connected with forest fire management in Bangladesh. The overuse of the rice straw and rice husk for paddy parboiling in the study area, also created the fodder crisis during the rainy season, as reported by the households. The average cowdung consump-

Tab. 1 - Different biomass fuel consumption by the household per month in the Meghna floodplain area of Bangladesh. (a) indicates standard error of mean, (b) represent the multiple responses of the households.

\begin{tabular}{lcc}
\hline \multicolumn{1}{c}{ Biomass types } & $\begin{array}{c}\text { Consumption of biomass } \\
\text { fuel (kg/month/household) }\end{array}$ & Households (\%) \\
\hline Bamboo & $58(15.26)^{\mathrm{a}}$ & $25^{\mathrm{b}}$ \\
Branches & $162(35.47)$ & 62 \\
Cowdung & $42.15(19.58)$ & 38 \\
Firewood & $144(23.65)$ & 62 \\
Leaves and twigs & $187(25.69)$ & 63 \\
Rice husk & $39.47(15.69)$ & 43 \\
Rice straw & $32.64(15.47)$ & 45 \\
\hline
\end{tabular}

tion was $42 \mathrm{~kg} \mathrm{month}^{-1}$ household ${ }^{-1}$, most of which were obtained from the own homestead and the rest was collected from the other sources. Generally, poor people used cowdung as fuel for cooking, but before the fuel crisis in the rural areas, cowdung was usually utilized as good manure in the agricultural land (pers. comm). So the present use of the cowdung as fuel for cooking is certainly decreasing the fertility of the agricultural lands resulting to the low productivity of the agricultural crops (Balat \& Ayar 2005). The environmental issues of this energy use in Bangladesh were well reported by Miah et al. (2009). The same situation is prevailing in other developing countries too.

The environmental degradation by the overuse of the firewood was discussed for Garhwal Himalaya, Uttaranchal, India (Bhatt \& Sachan 2004). Mahapatra \& Mitchell (1999) opines that overdependence of rural households on biofuel, especially on the fuelwood, affects both agricultural lands and forests. Mahiri (2003) addresses the same scarcity in the Nyando Disctrict, Kenya. Mlambo \& Huizing (2004) states the same issues at the village levels in Zimbabwe. Wijayatunga \& Attalage (2002) for Sri Lanka, Chen et al. (2006) for China, Liu et al. (2008) for Tibet, Balat \& Ayar (2005) for the developing country perspective, discussed on the serious environmental consequences of the biomass fuel use due to the un-sustainability of production. However, forest policy of Bangladesh should address the fuelwood needs of the populace and integrate the afforestation/reforestation initiatives to fulfill the fuelwood demands of the people. The main objective of the forest policy should be reaching at sustainable forest management. However, it requires active participation, integration and coordination of every stakeholder, from planning to implementation (Muhammed et al. 2008). Agricultural policy also should be adjusted with the changing forest policy.

\section{Collection of biomass and its end uses}

Three different sources of biomass fuel were identified in the study area. In accordance with priority ascending, those were own homestead and agricultural land, neighbor and market. The rural households obtained $74 \%$ of all the biomass fuels from their own homestead and agricultural land, $18 \%$ from neighbors and the rest $8 \%$ purchased from the market (Fig. 5). Miah et al. (2003) and Jashimuddin et al. (2006) also found almost the same results in other parts of Bangladesh.

The study indicated that most of the households were dependent on their own homesteads and agricultural lands as their main source of biomass fuel which had a great adverse impact on their agriculture and homestead forest. The rural household with no 
Tab. 2 - Expenditure of energy type in the Meghna floodplain area of Bangladesh. (a) indicates Standard error of mean.

\begin{tabular}{lcc}
\hline \multicolumn{1}{c}{ Fuel types } & $\begin{array}{c}\text { Expenditure } \\
\text { (US\$/month/household) }\end{array}$ & $\begin{array}{c}\text { Specific ratio of the } \\
\text { expenditure to the total } \\
\text { energy expenditure (\%) }\end{array}$ \\
\hline Biomass & $14.56(8.94)^{\mathrm{a}}$ & 68 \\
Kerosene & $2.14(1.5)$ & 10 \\
Electricity & $4.69(2.54)$ & 22 \\
\hline
\end{tabular}

enough sources of homestead, agricultural land, but had the purchasing capacity, they bought firewood or branches from the local market. But the households usually with not enough purchasing capacity were reported to collect biomass fuels from their neighbors.

The major uses of the biomass fuel were for cooking which comprised $83 \%$ of the total biomass energy consumption. The other uses of biomass fuel were for paddy parboiling, occasional heating and water boiling. Pokharel (2004) also states for the developing countries that household energy consumption is mostly used for cooking and it constitutes around half of the total energy use at the household level.

\section{Energy expenditure and its determi- nants}

Expenditure for total energy was $21.39 \pm$ 7.54 US\$ month $^{-1}$ household ${ }^{-1}$. The expenditure for biomass fuel was $14.56 \pm 8.94$ US\$ month $^{-1}$ household ${ }^{-1}$, while it was $4.69 \pm 2.54$ US\$ month $^{-1}$ household ${ }^{-1}$ for electricity and $2.14 \pm 1.5{\text { US } \$ \text { month }^{-1} \text { household }}^{-1}$ for kerosene. Among the total energy expenditure, biomass contributed to the largest portion of the expenditure, $68 \%$ followed by electricity $22 \%$ and kerosene $10 \%$ (Tab. 2). The ratio of the total energy expenditure to the total income of the household was around $11 \%$.

A negative relationship $(r=-0.86 ; p<0.01)$ was found between land ownership and biomass energy expenditure. Land ownership positively influenced the biomass fuel use. If a family owned large amount of land then they got maximum biomass fuels from their homestead and agricultural lands. They got firewood, branches, leaves and twigs from the homestead and rice straw, rice husk from the agricultural lands. So, they did not need to buy biomass fuels from the market, resulting to less expenditure for biomass fuel.

A significant relationship was found between income of the household and energy expenditure in the study area at $\mathrm{p}<0.05$ significance level. Explaining the relationship with the help of linear regression equation, we found, with $\mathrm{R}^{2}=0.88$, that $3.2 \%$ monthly income plus 12.529 (calculated in US\$) results to the total energy expenditure per month per household. If the income of the households increases they would spend more for their monthly energy consumption as a result they might be shifted from traditional energy consumption to higher priced modern energy consumption, provided that there will be enough modern energy supply to the rural areas. Most of the rural households had a low and sporadic income which affected the choice of selecting the energy use. Normally, the people who had the low income, used leaves and cowdung as biomass fuel for cooking, because they were unable to buy costly fuels.

It was found that family size of household and energy expenditure was significantly related at $\mathrm{p}<0.05$ significance level. But the correlation was not so stronger $(r=0.51)$. If the family size was larger, they spent more money for the households' energy expenditure provided that they had the sufficient buying capacity. But, with the increase of the family size, per capita energy expenditure was reduced. Pachauri (2004) also substantiates this claim.

Increasing income of the household dictates more expenditure for their energy consumption. The expenditure for energy consumption is often associated with poverty. As income rises, initially more fuel is concreases and the households want to shift to another improved one (Brouwer \& Falcáo 2004, Rao \& Reddy 2007).

\section{Conclusion}

Rural households were largely dependent on biomass fuel including firewood, branches, leaves and twigs, bamboo, rice straw, rice husk and cowdung. But leaves and twigs were found as the dominant fuel. The dependence on leaves and twigs and cowdung indicates the dwindling fuelwood resources in the homestead forests or near by rural jungles. The uses of cowdung also have the consequences to the reducing fertility in the agricultural soils. However, monthly income, family size and land ownership significantly influenced the biomass consumption and expenditure pattern in the rural households. Biomass provides the important renewable energy, which is presently advocated for the promotion throughout the world, as the capacity to reduce the global warming being a component of the carbon neutral system. But the situation in Bangladesh should be carefully understood in terms of the biodiversity of forests and agriculture. However, the use and production sumed but beyond a certain level, its use de- should be harmonized and sustainable through sustainable forest management.

\section{References}

Akhter J, Millat-e-Mustafa M, Khan NA, Alam MS (1999). Household biomass fuel energy situation of a forest rich district of Bangladesh. Bangladesh Journal of Agriculture 24 (1): 55-65. Arnold JEM, Khlin G, Persson R (2006). Woodfuels, livelihoods, and policy interventions: Changing Perspectives. World Development 34 (3): 596-611. - doi: 10.1016/j.worlddev.2005.08. 008

Balat M, Ayar G (2005). Biomass energy in the world, use of biomass and potential trends. Energy Sources 27 (10): 931-940. - doi: 10.1080/ 00908310490449045

BBS (2006). Statistical year book of Bangladesh. Statistics division, Ministry of planning, government of the people's Dhaka, Republic of Bangladesh.

Bhatt BP, Sachan MS (2004). Firewood consumption along an altitudinal gradient in mountain villages of India. Biomass and Bioenergy 27 (1): 69-75. - doi: 10.1016/j.biombioe.2003.10.004

Brouwer R, Falcáo MP (2004). Wood fuel consumption in Maputo, Mozambique. Biomass and Bioenergy 27 (3): 233-245. - doi: 10.1016/j.biombioe.2004.01.005

Chen L, Heerink N, van den Berg M (2006). Energy consumption in rural China: a household model for three villages in Jiangxi Province. Ecological Economics 58 (2): 407-420. - doi: 10.1016/j.ecolecon.2005.07.018

Flannigan M (2006). Fire research: where we are and where are we going? Forest Ecology and Management 234 (S1): 8. - doi: 10.1016/j.foreco.2006.08.022

Gupta G, Köhlin G (2006). Preferences for domestic fuel: analysis with socio-economic factors and rankings in Kolkata, India. Ecological Economics 57: 107-121. - doi: 10.1016/j.ecolecon. 2005.03.010

Heltberg R (2004). Fuel switching: evidence from eight developing countries. Energy Economics 26 (5): 869-887. - doi: 10.1016/j.eneco.2004.04. 018

Hossain MMG (2003). Improved cookstove and biogas programmes in Bangladesh. Energy for Sustainable Development 7 (2): 97-100. - doi: 10.1016/S0973-0826(08)60359-2

Iftekhar MS (2006). Forestry in Bangladesh: an overview. Journal of Forestry 104 (3): 148-153.

Jashimuddin M, Masum KM, Salam MA (2006). Preference and consumption pattern of biomass fuel in some disregarded villages of Bangladesh. Biomass and Bioenergy 30 (5): 446-451. - doi: 10.1016/j.biombioe.2005.11.023

Joon V, Chandra A, Bhattacharya M (2009). Household energy consumption pattern and socio-cultural dimensions associated with it: A case study of rural Haryana, India. Biomass and Bioenergy 33 (11): 1509-1512. - doi: 10.1016/j.biombioe.2009.07.016

Liu G, Lucas M, Shen L (2008). Rural household energy consumption and its impacts on eco-en- 
vironment in Tibet: taking taktse county as an example. Renewable and Sustainable Energy Reviews 12 (7): 1890-1908. - doi: 10.1016/j.rser 2007.03.008

Mahapatra AK, Mitchell CP (1999). Biofuel consumption, deforestation, and farm level tree growing in rural India. Biomass and Bioenergy 17 (4): 291-303. - doi: 10.1016/S0961-9534(99) 00056-2

Mahiri IO (2003). Rural household responses to fuelwood scarcity in Nyando district, Kenya. Land Degradation and Development 14 (1): 163 171. - doi: 10.1002/ldr.535

Martín LD, Diez AG, Soriano LR, Diez ELG (1997). Meteorology and forest fires: conditions for ignition and conditions for development. Journal of Applied Meteorology 36 (6): 705-710. - doi: 10.1175/1520-0450-36.6.705

Miah MD, Ahmed R, Uddin MB (2003). Biomass fuel use by the rural households in Chittagong region, Bangladesh. Biomass and Bioenergy 24 (4/5): 277-283. - doi: 10.1016/S0961-9534(02) 00173-3

Miah MD, Rashid HA, Shin MY (2009). Wood fuel use in the traditional cooking stoves in the rural floodplain areas of Bangladesh: A socio-environmental perspective. Biomass and Bioenergy 33 (1): 70-78. - doi: 10.1016/j.biombioe.2008. 04.015

Mlambo D, Huizing H (2004). Household responses to fuelwood scarcity: A case study of two villages in Zimbabwe. Land Degradation and Development 15 (3): 271-281. - doi: 10.1002/ 1dr. 614

Muhammed N, Koike M, Haque F (2008). Forest policy and sustainable forest management in Bangladesh: an analysis from national and international perspectives. New Forests 36 (2): 201216. - doi: 10.1007/s11056-008-9093-8

Pachauri S (2004). An analysis of cross-sectional variations in total household energy requirements in India using micro survey data. Energy Policy 32 (15): 1723-1735. - doi: 10.1016/S0301-4215 (03)00162-9

Palmer C, Macgregor J (2009). Fuelwood scarcity, energy substitution, and rural livelihoods in Namibia. Environment and Development Economics 14 (6): 693-715. - doi: 10.1017/ S1355770X08005007

Pokharel S (2004). Energy economics of cooking in households in Nepal. Energy 29 (4): 547-559. - doi: 10.1016/j.energy.2003.10.015

Rao MN, Reddy BS (2007). Variations in energy use by Indian households: an analysis of micro level data. Energy 32 (2): 143-153. - doi: 10.1016/j.energy.2006.03.012

Sarker MAR, Islam SMN (1998). Rural energy and its utilization in Bangladesh. Energy 23 (9): 785-789. - doi: 10.1016/S0360-5442(98)00018-8 Sattar MA, Bhattacharjee DK, Kabir MF (1999). Physical and mechanical properties and uses of timbers of Bangladesh. Bangladesh Forest Re- search Institute, Chittagong, Bangladesh. Sudha P, Ravindranath NH (1998). Land availability and biomass production potential in India. Biomass and Bioenergy 16 (3): 207-221. - doi: 10.1016/S0961-9534(98)00083-X

Sudha P, Somashekhar HI, Rao S, Ravindranath NH (2003). Sustainable biomass production for energy in Inda. Biomass and Bioenergy 25 (5): 501-515. - doi: 10.1016/S0961-9534(03)00087-4 Van Ruijven B, Urban F, Benders RMJ, Moll HC, Van der Sluijs J, De Vries B, Van Vuuren DP (2008). Modeling energy and development: an evaluation of models and concepts. World Development 36 (12): 2801-2821. - doi: 10.1016/j.worlddev.2008.01.011

Wijayatunga PDC, Attalage RA (2002). Analysis of household cooking energy damand and its environmental impact in Sri Lanka. Energy Conversion and Management 43 (16): 2213-2223. doi: 10.1016/S0196-8904(01)00159-5

Wright SJ, Sanchez-Azofeifa GA, Portillo-Quintero C, Davies D (2007). Poverty and corruption compromise tropical forest reserves. Ecological Applications 17 (5): 1259-1266. - doi: 10.1890/ 06-1330.1

Xiaohua W, Zhenming F (1996). Survey of rural household energy consumption in China. Energy 21 (7/8): 703-705. - doi: 10.1016/0360-5442 (96)00019-9 